\title{
IMPLEMENTATION OF ONLINE EDUCATION DURING THE GLOBAL COVID-19 PANDEMIC: PROSPECTS AND CHALLENGES
}

\author{
Sri Haryati ${ }^{1 *}$, Sukarno Sukarno ${ }^{1}$, Sugeng Purwanto ${ }^{2}$ \\ ${ }^{1}$ Universitas Tidar, Magelang, Indonesia \\ ${ }^{2}$ Universitas Stikubank, Semarang, Indonesia \\ * e-mail: sriharyati@untidar.ac.id
}

\begin{abstract}
Due to an abrupt outbreak of the global COVID-19 pandemic, the educational paradigm has to be shifted to a new era of online education at all levels while maintaining the Sustainable Development Goals (SDGs). The study aims to analyze the implementation of online education focusing on (1) institutional preparedness of digital infrastructure and (2) students' learning activities during the pandemic. An online survey (Google Survey) was conducted to collect the data, which were then qualitatively analyzed supported by data quantification in percentage. The findings indicate that the target schools managed to carry out online education in response to the government's social restriction. Online education has been implemented in three different contexts, depending on the types and strata of schools-fully, partially, and none of the two. This has opened up prospects and challenges to create different standpoints. The students learn through a variety of virtual learning activities, such as watching videos (YouTube or Teacher's presentation), completing quizzes, doing assignments, discussion via Google Meet, and the like depending on the class design.
\end{abstract}

Keywords: online education, COVID-19 pandemic, digital literacy, virtual learning activities, class design

\section{PELAKSANAAN PENDIDIKAN DARING DI MASA WABAH COVID-19: PROSPEK DAN TANTANGAN}

\begin{abstract}
Abstrak: Akibat wabah global COVID-19 yang tiba-tiba merebak, paradigma pendidikan harus dialihkan ke era baru yang berupa pendidikan daring pada semua jenjang sekaligus menjaga ketercapaian Sustainable Development Goals (SDGs). Penelitian ini bertujuan untuk menganalisis implementasi pendidikan daring dengan fokus pada (1) kesiapan kelembagaan terkait infrastuktur digital dan (2) kegiatan belajar siswa selama pandemi. Data yang terkumpul melalui survei daring (Google Survey) kemudian dianalisis secara kualitiatif dengan didukung oleh kuantifikasi data berupa persentase. Temuan menunjukkan bahwa sekolah binaan berhasil melaksanakan pendidikan daring sebagai tanggapan terhadap pembatasan sosial pemerintah selama masa pandemi. Sekolah memulai pembelajaran daring pada tiga konteks yang berbeda, tergantung jenis dan strata sekolah ada yang secara penuh, sebagian, atau tidak keduanya. Hal ini telah membuka prospek dan tantangan yang mengakibatkan munculnya sudut pandang yang berbeda. Para siswa belajar melalui berbagai kegiatan pembelajaran virtual, seperti menonton video (YouTube atau presentasi Guru), menyelesaikan kuis, mengerjakan tugas, diskusi melalui Google-Meet, dan sejenisnya tergantung pada desain pembelajaran.
\end{abstract}

Kata Kunci: pendidikan daring, pandemi COVID-19, literasi digital, aktivitas pembelajaran daring, desain pembelajaran

\section{INTRODUCTION}

The outbreak of coronavirus has jeopardized everything. We are challenged to research responses to the outbreak regarding the implementation of online education at schools throughout the regent, employing digital literacy on both students and teachers (Rusydiyah et al., 2020). The coronavirus was first detected in Wuhan, China, as pneumonia of unknown cause. The case was reported to the WHO Country Of- fice on December 31, 2019. It was declared a Public Health Emergency of International Concern on January 30, 2020. WHO then announced a name for the new corona-virus disease, COVID-19 (Sohrabi et al., 2020).

It was not until March 2, 2020, that two people in Indonesia were confirmed positive for the coronavirus (Ryalino, 2020). At first, it was argued that coronavirus would not affect Indonesia with such a hot climate (Nasir et al., 
2020). It turned otherwise. Coronavirus goes international and is known as the COVID-19 Pandemic.

Instead of a total lockdown, the Government of the Republic of Indonesia announced a large-scale social restriction' to cut the spread of COVID-19 (Setiati \& Azwar, 2020). Everyone is supposed to stay at home. Fortunately, some of us have been accustomed to ordering almost anything in just a few clicks from our mobile phones (smartphones). Some others are not lucky enough to do so and, thus, have to go out for work with a strict protocol of COVID-19wear-ing masks, keeping social distancing and most importantly, avoiding crowds of people. Schools are closed, and students should take online learn-ing through various types of Learning Manage-ment Systems (LMS). This is not a problem since the ownership of electronic devices used for cyber activities is very high. An individual may have more than one smartphone and or laptop. Even, it can be said that smartphones are not any more luxurious things (Safaria, 2016). In other words, online learning does not seem to be a problem.

However, it is important to know the real impacts of COVID-19 is to anticipate educational practices during and after the Pandemic with the implementation of online education. For this purpose, an online survey (Google Form) was conducted to get information from Elementary, Junior High, Senior High and Vocational Senior High Schools focusing on issues such as the distri-bution of schools implementing (fully, partially, none) online learning, mastery of digital literacy for teachers and students, ease of access to the internet, the preparedness of schools concerning the digital infrastructure, and most interestingly, what to do next after the worldwide COVID-19 pandemic would finally end. It was beyond the start-up of the study as the Pandemic was all of a sudden around us. Had such a pandemic not occurred, the research would have dealt with regular educational practices.

However, before dealing with the COVID-19 Pandemic as an immediate God's visitation affecting the overall process of education, we would like to review the related literature to highlight relevant issues to position the current study within a research community. There was a bit of difference concerning the current research compared with the one performed five years ago, namely with an additional concern of the unex-pected Pandemic as a point of departure, resulting in the obligation to implement online education at all levels of education, and still supporting the achievement of Sustainable Development Goals (SDGs) in anticipation of Society 5.0.

Based on the SDGs with the four pillars of implementation, namely social development, economic development, environmental development, and law and governance development (Sachs, 2012), as also ruled out by the Indonesian Government (Rahma et al., 2019), the educatio-nal paradigm has to be shifted to a new era of digital education due to an abrupt outbreak of the global COVID-19 Pandemic. However, such a situation can undoubtedly represent 'an earlier implementation of Society 5.0' upon the emergence of Industrial Revolution 4.0, where people are provided with easy access to almost everything from home to achieve a sustainable society for human security and well-being through a cyber-physical system (Shiroishi et al., 2018).

Research regarding online education has been conducted to identify views from different perspectives. Toquero (2020) conducted a study to investigate the challenges and opportunities during COVID-19 in the Philippines context. It was argued that very few studies had been done regarding the effect of the Pandemic on education as studies concerning health have taken up attention. This research recommended improvement of educational modes of delivery; higher education should integrate the curricula into com-patible versions with the technological advances. Chances are widely open to welcome digitized education. However, Students' perspectives on 'online learning' amid COVID19 have been investigated (Adnan \& Anwar, 2020) to find out that online education was a problem for under-developed areas in Pakistan as many students did not get access to cyber technology. Therefore it was high time that the implementation of online education during COVID-19 be conducted to get informed of the real challenges and opportunities which may differ from one area to another throughout Indonesia (Aji et al., 2020) in which it was argued that blended learning (mixed modes of online and offline) was used in some schools before the pandemic. At that time, e-learning was still considered to be peripheral (Pham \& Ho, 2020) and used only to accommodate assign-ments and some additional quizzes. However, the pandemic has turned things otherwise. Nowa-days, education has to be carried out 
online or virtually (Alam et al., 2021). Thus, the current study filled up the research gap(s) before and during the pandemic, most importantly since Indonesia's education has not been equally dispersed. Discrepancies are still found between the central and peripheral educational services, between the rich and the poor areas, and the like.

The purpose of the current study is to analyze the implementation of online education in Magelang regency/municipality as one of the educational clusters in Central Java. Issues discussed herein include (1) preparedness of schools to reflect the condition of digital infrastructure and (2) students' online learning experiences to reflect the condition of digital literacy regarding the teachers and the students.

\section{METHODS}

The current study is qualitative and interpretative. It is qualitative as it does not involve sophisticated statistical calculation. Numbers (automatic calculation by Google) used in the data analysis were limited to proportion or percentage-simply being categorical and phenomenological. The phenomena in the field were interpreted based on the researchers' expertise to arrive at the findings and discussion. It is relevant following the type of survey being conducted (Adam, 2020).

A stratified random sampling technique of $1 \%$ of the total number of teachers in each school from the Regional Education Office of Magelang Municipality (Regency), Central Java. Ninety-two teachers participated in the Online Survey (Google Form). The research instrument was collaboratively constructed in a Focus Group Discussion (FGD), tried out in a limited scope, and revised accordingly before being distributed to the research subjects via emails. The data concerning the preparedness of schools regarding digital infrastructure (internet and LMS), including the teachers' digital literacy in LMS operations, were digitally collected. Meanwhile, from teachers' perspectives, the students' learning experiences regarding what they were doing during the online learning were also recorded through follow-up video calls with randomly selected research subjects, as triangulated in a study (Lallukka et al., 2020) interviewing one teacher who fully implemented e-learning, one teacher who partly implemented e-learning, and also one teacher who did not implement e-learning. For more details, data on research subjects can be seen in Table 1 .
The collected data were then analyzed for further discussion in a comprehensive narrative to reveal the current position of Indonesia's online education. In addition to the school categories and their implementations of online education, the issues encountered during the online services were also tabulated regarding teachers' digital literacy levels, use of LMS, modes of interpersonal communication, and expectations of online education after the Pandemic. It is important to note that the data regarding school conditions were taken from the Regional Education Office of Magelang Municipality as the basis of findings and discussion.

\section{Table 1. Research Subjects}

\begin{tabular}{clcc}
\hline No. & \multicolumn{1}{c}{ Institution } & $\sum$ Subjects & \% \\
\hline 1. & Elementary School & 50 & 54 \\
2. & Junior High School & 22 & 24 \\
3. & Senior High School & 9 & 10 \\
4. & Vocational Senior High & 11 & 12 \\
& Total Subjects & 92 & 100 \\
\hline
\end{tabular}

The follow-up interviews were aggregated in a comprehensive narrative to reveal how the teachers and students innovatively performed during the online teaching and learning activities as a new paradigm of online education in place of the normal 'offline' school activities. Virtual activities through video conferences (Zoom or Google Meet) were also highlighted to complete the overall online activities.

\section{FINDINGS AND DISCUSSION}

Presented below are findings and discussion upon which to comprehensively cover the essence of the current study in response to the two research problems, namely (1) institutional preparedness of digital infrastructure and (2) students' virtual learning activities, regarding the types of educational innovation to cover the overall educational system.

\section{Findings}

Regarding the implementation of online education during the COVID-19 pandemic in Magelang Municipality/Regency, the results can be seen in Table 2 .

During the global COVID-19 pandemic, all schools in Magelang Municipality have so far implemented 'Stay-at-Home' learning or online learning with the exception of Elementary schools with Disabilities due to absences of data concerning this kind of school. The rest of the two Elementary Schools and one Senior High School located in remote areas may have employed a very simple model of online 
learning (using WhatsApp) and required offline submission of assignments. Therefore, they responded 'no online learning' to the survey. In this special case, parents of the elementary schools and individual students of the one Senior High School may have to submit written works (assignments) offline (in-person to the school teachers on the due dates). Most teaching materials are still in hardcopies; only a few (screenshots) can be submitted via email or WhatsApp. Thus, initial discovery reveals that online education has been implemented with varying degrees of quality assurance-generating terms, such as 'fully-implemented', 'partially implemented' and 'none of the two'.

Each of the three conditions specified herein is further discussed to find out the real practices in the fields and hence to give a much clearer description of the context of the situation. Smartphones and laptops are mostly used as the main tools to get access to online learning with full internet access with or without LMS. Elementary School students may need parental guidance and supervision. Video conferences (calls) utilizing Zoom and Google Meet have also been used in place of face-to-face interactions. These two facilities employ a strict attendance policy, and participation is mostly practised beyond Elementary Schools.

The survey also yielded special issues in the implementation of online education during COVID-19, as exhibited in Table 3. From Table 3 , it is convincing that teachers are categorized as 'well-equipped 'fair', and 'poor' in terms of digital literacy, although abundant chances for improvement ahead are widely open. Meanwhile, internet budgeting seems to be quite a problem apart from a poor internet connection and institutional support. More teachers have been using LMS as compared with Non-LMS. WhatsApp and email were also used as a means of communication. Those teachers who have signed up to a particular kind of LMS of interest to create a course work for their students, enjoy the features of LMS-which will be further elaborated in the discussion. Other issues that are of no least importance are described in Table 4.

As seen from Table 4, interpersonal communication has already been quite wellmanaged. More teachers utilize WhatsApp as compared with the use of a phone (mobile phone) and the very minimum of SMS. Meanwhile, regarding the future of online education, most teachers responded positively to the continuation of the online system, with only very few expressing negative attitudes. This is a good point as we are heading for Society 5.0, where most of our activities are digitally based. We are pretty optimistic since most of the students have managed to participate in the LMS. The rest can be easily trained since they are digital natives. Unfortunately, we have to pay particular attention to honesty practice. Some teachers believe that the students are honest in doing online assignments or examinations. Meanwhile, another group of teachers is in doubt, and a few of them claim that the students are dishonest.

Regarding the teaching and learning activities, the results of the survey can be seen in Table 5. Teachers and students have been challenged with the employment of new technological innovations, especially the total exposure of online education, despite the unfavourable facts that not all individuals have access to such innovations. In other words, digital infrastructure has not been fully established.

In Table 5, teaching and learning activities in online learning are presented through a LMS. The teachers carried out the teaching process by uploading teaching materials, copying and pasting links of YouTube vidoes or websites, writing up learning modules, including exercises of various types, giving feedbacks, making quizzes and assignments, setting up chat or forum rooms, or setting up Google meets.

In one session, as the interview revealed, a teacher can design learning activities by the features of the LMS. The students learn the materials of which their mastery can be assessed through quizzes and assignments (case studies). Quizzes are of various kinds, such as essays, multiple choices, blank filling, matching, truefalse, etc. Meanwhile, for the assignments, students may be asked to write responses to the teacher's questions based on video watching, journal articles, and or PPT presentations. They may also be assigned to upload video recordings of their presentation on specific issues at one time or another.

Teleconference (Google Meet) enables an online class to perform multiple communication on special issues, depending on the teacher's teaching design, mostly leading to class discussion. Chatting and forum discussion may serve as other forms of written discussions on matters related to the current lesson. In this case, the teacher can monitor his or her students' activities. 
Table 2. Implementation of Online Education during COVID-19 Pandemic

\begin{tabular}{|c|c|c|c|c|c|c|c|c|c|}
\hline \multirow{3}{*}{ No. } & \multirow{3}{*}{ School Category } & \multirow{3}{*}{$\Sigma$} & \multirow{3}{*}{$\%$} & \multicolumn{6}{|c|}{ Implementation of Online Education } \\
\hline & & & & \multicolumn{2}{|c|}{ Full } & \multicolumn{2}{|c|}{ Partial } & \multicolumn{2}{|c|}{ None } \\
\hline & & & & $\sum$ & $\%$ & $\sum$ & $\%$ & $\sum$ & \\
\hline 1. & Elementary School & 50 & 54 & 19 & 38 & 29 & 58 & 2 & 4 \\
\hline 2. & Junior High School & 22 & 24 & 21 & 95.5 & 1 & 4.5 & & \\
\hline 3. & Senior High School & 9 & 10 & 7 & 77.8 & 1 & 11.1 & 1 & 11.1 \\
\hline \multirow[t]{2}{*}{4.} & Vocational Senior High School & 11 & 12 & 11 & 100 & & & & \\
\hline & & 92 & 100 & 58 & 63.1 & 31 & 33.6 & 3 & 3.3 \\
\hline
\end{tabular}

Table 3. The Use of Technology during COVID-19

\begin{tabular}{clcc}
\hline No. & Problem & Total & Percent \\
\hline 1. & Digital Literacy & & 17.5 \\
& $\checkmark$ Very good & 16 & 44.5 \\
& $\checkmark$ Good & 41 & 36.9 \\
& $\checkmark$ Fair & 34 & 1.1 \\
& $\checkmark$ Poor & 1 & 19.5 \\
2. & $\checkmark$ Internet (Teacher) & 18 & 64.2 \\
& $\checkmark$ Connection & 59 & 16.3 \\
& $\checkmark$ Budgeting & 15 & 64.1 \\
& $\checkmark$ Institutional supports & 59 & 27.2 \\
Use of LMS & & 8.7 \\
& Non-LMS & 25 & 39.1 \\
& $\checkmark$ WhatsApp (WA) & 8 & 60.9 \\
\hline
\end{tabular}

Table 4. Other Issues during COVID-19

\begin{tabular}{|c|c|c|c|}
\hline No. & Issues & Total & Percent \\
\hline \multirow[t]{4}{*}{1.} & Interpersonal Communication & & \\
\hline & $\checkmark$ SMS & 1 & 1.1 \\
\hline & $\checkmark \quad$ WhatsApp (WA) & 62 & 67.4 \\
\hline & $\checkmark \quad$ Phone & 29 & 31.5 \\
\hline \multirow[t]{4}{*}{2.} & Future of Online Education & & \\
\hline & $\checkmark \quad$ Very likely & 21 & 22.8 \\
\hline & $\checkmark \quad$ Likely & 64 & 69.6 \\
\hline & $\checkmark \quad$ Unlikely & 7 & 7.6 \\
\hline \multirow[t]{5}{*}{3.} & Student's Submission of Assignments & & \\
\hline & $\checkmark \quad$ Email reply & 8 & 8.7 \\
\hline & $\checkmark \quad$ Uploading to LMS & 59 & 64.2 \\
\hline & $\checkmark \quad$ WhatsApp & 22 & 23.9 \\
\hline & $\checkmark \quad$ Submitting in person & 3 & 3.2 \\
\hline \multirow[t]{4}{*}{4.} & Students' honesty in teachers' minds & & \\
\hline & $\checkmark \quad$ Yes & 37 & 40.2 \\
\hline & $\checkmark \quad$ Maybe & 40 & 43.5 \\
\hline & $\checkmark \quad$ No & 15 & 16.3 \\
\hline
\end{tabular}

\section{Table 5. Teaching-Learning Activities in Online Education (LMS)}

\begin{tabular}{|c|c|c|}
\hline \multirow{2}{*}{ No. } & \multicolumn{2}{|r|}{ Activities } \\
\hline & Teaching & Learning \\
\hline 1. & Uploading materials (e-books) & Downloading materials (e-books) \\
\hline 2. & Copying/Pasting links (YouTube or Web) & Clicking on the links to watch videos or to browse the webs \\
\hline 3. & $\begin{array}{l}\text { Writing up learning modules, including } \\
\text { exercises of various types }\end{array}$ & $\begin{array}{l}\text { Reading the modules and doing the exercises to show } \\
\text { comprehension and improvement of knowledge and skills }\end{array}$ \\
\hline 4. & Giving feedbacks & $\begin{array}{l}\text { Receiving feedbacks for self-introspection and further } \\
\text { improvement }\end{array}$ \\
\hline 5. & Presenting PPT & Participating in teacher's presentation \\
\hline 6. & Making quizzes, assignments & Doing quizzes, assignments, uploading answers \\
\hline 6. & Setting up chat or forum rooms & Participating in the chats and forums \\
\hline 7. & Setting up Google Meet & Participating in teleconference \\
\hline
\end{tabular}


The activities mentioned above have opened up a new model of teaching with the main difference in the physical absence of a teacher and fellow students-as all done online. The LMS's are centrally operated by the institutions' digital infrastructure. In these LMS, school principals have access to overall monitoring of the teachers' activities. However, personal communication may be done via WhatsApp or mobile phone calls.

Another interview was done with a teacher who-as claimed-has performed partial implementation of e-learning using web-based elearning. Individual teachers solely manage it. It is claimed that the "Weebly education platform is an attempt to bring teachers and students closer online. Both teachers and students will have individual accounts to create a site and perform their tasks." Depending on the lesson(s) of which he or she is in charge, each teacher can create his or her account(s). In this case, a teacher may simply follow a step-by-step tutorial to build his or her online course design.

Another interview was done with a teacher who claimed not to implement online classes since no LMS platform was used. During the pandemic, this teacher has made a WhatsApp Group (WAG) in which the membership is limited to the students and their teacher of a particular class subject. Activities that can be performed using WAG include sending and receiving document files, photos and videos. A teacher may send instructions, quizzes, assignments (based on the Workbooks at students' homes). Students complete the tasks and send the answers via WAG. Parental guidance is required for the students of Elementary Schools since some still have to submit the completed workbooks in person to the teacher at school in exchange for the next assignment. Occasional offline meetings (once or twice a week under strict health protocols) are still held by individual teachers to summarize the materials and discuss important issues.

\section{Discussion}

The findings have quite clearly highlighted the implementation of online learning during the global COVID-19 pandemic for Elementary School, Junior High School, Vocational Senior High School, and Public Senior High School in three different ways-fully implemented, partially implemented, and none of the two-that have been described above.
Our first impression of the implementation of online education in Elementary schools is that it is not yet well done since most schools have not fully implemented the program. Instead, they use web-based e-learning, which teachers individually manage. In this case, there is no other way than to build more digital infrastructure in those schools which have not fully implemented online education. It is in line with and in support of research (Garad et al., 2021). It is the responsibility of the institutions to fully build their digital infrastructure to support the implementation of distant learning. We believe that digital infrastructure is obligatory regardless of the level of education. What matters is the appropriateness for each level. However, solving one problem (digital infrastructure) may create another problem, namely budgeting. For state schools, all are centralized by the local government in which all depend on the fund allocated for education within a particular academic year. New things cannot be proposed in the middle of the budgeting tenor. In other words, everything shall be planned in a five-year development plan, as exemplified in a study (Xiao, 2019). Meanwhile, private schools are differently managed in terms of any procurement of educational infrastructure. They are mostly dependent on the community financial supports, although some may have other revenuegenerating means.

Another issue of importance upon building digital infrastructure is to train the human resources adequately so that the LMS can be maximally used, as evidenced in research among economics teachers (Sojanah et al., 2021). It is true that digital infrastructure means nothing without the support of adequate competency of human resources. In other words, digital literacy has to be developed on a regular basis to match with technological updates and upgrades.

We do not mean to say that the use of webbased e-learning is discouraged since it can be integrated into the central institutional digital infrastructure for supervisory purposes. One example is the use of EDMODO, as evidenced in research (Sumardi \& Muamaroh, 2020), in which it was claimed that EDMODO was effective for use in ELS class to promote online class interactions apart from the implementation of Computer-Based Test (CBT). Other software applications are available for use on both free and paid platforms.

Teachers' and students' digital literacy skills have to be developed. These are the challenges we have to encounter, as evidenced in 
research (Perdana et al., 2020), in which it was claimed that the levels of Indonesian students' digital literacy were still very low, and therefore the Online laboratory Simulation with Concept Mapping and Problem-Based Learning (OLSCPMBL) Model was proposed to improve the students' digital literacy skills. We have somehow mentioned that millennial students have very high adaptability with respect to cyber technology. This is simply because they are digital natives - contrary to their seniors who have been, in some cases, fossilized to the use of offline technology of education. Only very recently have they been introduced to blended learning (peripheral in nature) and finally to fully online education due to the outbreak of the COVID-19 pandemic as a blessing in disguise. Some, however, have managed to comply with the demand for educational innovations in the current implementation of online education.

There has been a totally new paradigm in education as experienced by both teachers and students. Distant learning has now gained its place, not just an additional activity such as in blended learning but predicted as a mainstream platform. This is a prospect supported by research (Palvia et al., 2018). It was researched in terms of worldwide status, challenges, trends and implications to forecast its mainstream educational platforms by 2025 . It has also been strengthened in research (Zhou et al., 2020), featuring China termed as 'School Out' but 'Class On, the largest online education in the world today. This very likely occurs all over the world with different challenges and treatments.

Teachers' teaching activities and students' learning experiences have extraordinarily changed. A teacher maximizing the use of features in LMS has to design his or her online classes which his or her students from anywhere can access. Likewise, a student has to read ebooks and watch video presentations to improve his or her knowledge with assessment models performed online, from doing quizzes and assignments to making his or her final projects a partial requirement for graduation. This is another prospect for a new educational platforman online assessment system. In this respect, digital literacy, therefore, needs to be improved on the part of teachers and students alike to stay informed of all advances in cyber educational technology-updated and upgraded on a regular basis.

One point of departure for the development of education and civilization is that everyone has to adopt him- or herself in the 'new normal'-living with new social norms, toward agreed, approved social transactions in all walks of life, including education as prospects. They are new things that people did not even have in mind, such as having online classes (independent learning experiences). Online education, which used to be labelled as "Second Choice" has now been accepted as the mainstream platform of education. E-learning activities that used to be thought of as being supplementary are now the main forms of education. Everyone is challenged to comply with the new systems by improving digital literacy in accordance with advanced digital infrastructure.

\section{CONCLUSION}

In response to the abrupt outbreak of the global COVID-19 pandemic, online education has to be implemented in all strata of schooling to maintain the Sustainable Development Goals (SDGs). The survey and follow-up interviews reveal that the target schools managed to carry out online education in compliance with the government's social distancing. Depending on the types and strata of schools, the implementation of online education has been undertaken in three different contexts-fully, partially and none of the two. This has opened up prospects and challenges to create different standpoints (new educational platforms). The students have experienced a variety of virtual learning activities, such as reading e-books, watching videos (YouTube or Teacher's presentation), completing quizzes, doing an assignment, discussing via Google-Meet, and the like depending on the teacher's course design. Everyone is challenged to equip him- or herself in a new learning environment to independently cope up with possible learning problems-lack of physical contacts, yet abundant resources of information which can be accessed through internet facilities.

\section{ACKNOWLEDGEMENTS}

Our thanks and gratitude shall definitely go to the Board of Regional Development (BAPEDA) for the research grant. Secondly, school teachers whose participation in the current study cannot go without, we are deeply indebted to their invaluable contributions.

\section{REFERENCES}

Adam, I. O. (2020). Using a qualitative interpretive approach in educational technology implementation. In Handbook of Research on Managing Information 
Systems in Developing Economies (pp. 318-331). IGI Global. https://doi.org/10.4018/978-1-7998-26101.ch015

Adnan, M., \& Anwar, K. (2020). Online learning amid the COVID-19 pandemic: Students' perspectives. Journal of Pedagogical Sociology and Psychology, 2(1), 45-51. https://doi.org/10.33902/JPSP. 2020261309

Aji, W. K., Ardin, H., \& Arifin, M. A. (2020). Blended learning during pandemic corona virus: Teachers' and students' perceptions. IDEAS: Journal on English Language Teaching and Learning, Linguistics and Literature, 8(2), 632-646. https://doi.org/10.24256/ideas.v8i2.1696

Alam, M. M., Ahmad, N., Naveed, Q. N., Patel, A., Abohashrh, M., \& Khaleel, M. A. (2021). E-learning services to achieve sustainable learning and academic performance: An empirical study. Sustainability, 13(5), 2653. https://doi.org/10.3390/su13052653

Garad, A., Al-Ansi, A. M., \& Qamari, I. N. (2021). The role of e-learning infrastructure and cognitive competence in distance learning effectiveness during the covid-19 pandemic. Jurnal Cakrawala Pendidikan, 40(1), 81-91. https://doi.org/10.21831/cp.v40i1.33474

Lallukka, T., Pietiläinen, O., Jäppinen, S., Laaksonen, M., Lahti, J., \& Rahkonen, O. (2020). Factors associated with health survey response among young employees: a register-based study using online, mailed and telephone interview data collection methods. BMC Public Health, 20(1), 184. https://doi.org/10.1186/s12889-020-8241-8

Nasir, N. M., Baequni, B., \& Nurmansyah, M. I. (2020). Misinformation related to COVID19 in Indonesia. Jurnal Administrasi Kesehatan Indonesia, 8(2), 51-59. https://doi.org/10.20473/jaki.v8i0.2020.5159

Palvia, S., Aeron, P., Gupta, P., Mahapatra, D., Parida, R., Rosner, R., \& Sindhi, S. (2018). Online education: Worldwide status, challenges, trends, and implications. Journal of Global Information Technology Management, 21(4), 233-241. https://doi.org/10.1080/1097198X.2018.15 42262
Perdana, R., Jumadi, J., Rosana, D., \& Riwayani, R. (2020). The online laboratory simulation with concept mapping and problem based learning (ols-cmpbl): Is it effective in improving students' digital literacy skills? Jurnal Cakrawala Pendidikan, 39(2), 382-394. https://doi.org/10.21831/cp.v39i2.31491

Pham, H.-H., \& Ho, T.-T.-H. (2020). Toward a 'new normal' with e-learning in Vietnamese higher education during the post COVID-19 pandemic. Higher Education Research \& Development, 39(7), 1327-1331.

https://doi.org/10.1080/07294360.2020.18 23945

Rahma, H., Fauzi, A., Juanda, B., \& Widjojanto, B. (2019). Development of a composite measure of regional sustainable development in Indonesia. Sustainability, 11(20), 5861. https://doi.org/10.3390/su11205861

Rusydiyah, E. F., Purwati, E., \& Prabowo, A. (2020). How to use digital literacy as a learning resource for teacher candidates in Indonesia. Jurnal Cakrawala Pendidikan, 39(2), 305-318.

https://doi.org/10.21831/cp.v39i2.30551

Ryalino, C. (2020). How Indonesia copes with coronavirus disease 2019 so far (part one): The country, the government, and the society. Bali Journal of Anesthesiology, 4(2), 33.

Sachs, J. D. (2012). From millennium development goals to sustainable development goals. The Lancet, 379(9832), 2206-2211. https://doi.org/10.1016/S01406736(12)60685-0

Safaria, T. (2016). Prevalence and impact of cyberbullying in a sample of Indonesian junior high school students. Turkish Online Journal of Educational TechnologyTOJET, 15(1), 82-91.

Setiati, S., \& Azwar, M. K. (2020). COVID-19 in Indonesia. Acta Medica Indonesiana, 52(1), 84-89. http://actamedindones.org/index.php/ijim/a rticle/view/1426

Shiroishi, Y., Uchiyama, K., \& Suzuki, N. (2018). Society 5.0: For human security and well-being. Computer, 51(7), 91-95. https://doi.org/10.1109/MC.2018.3011041 
Sohrabi, C., Alsafi, Z., O’Neill, N., Khan, M., Kerwan, A., Al-Jabir, A., Iosifidis, C., \& Agha, R. (2020). World Health Organization declares global emergency: A review of the 2019 novel coronavirus (COVID-19). International Journal of Surgery, 76, 71-76. https://doi.org/10.1016/j.ijsu.2020.02.034

Sojanah, J., Suwatno, S., Kodri, K., \& Machmud, A. (2021). Factors affecting teachers' technological pedagogical and content knowledge (A survey on economics teacher knowledge). Jurnal Cakrawala Pendidikan, 40(1), 1-16. https://doi.org/10.21831/cp.v40i1.31035

Sumardi, S., \& Muamaroh, M. (2020). Edmodo impacts: Mediating digital class and assessment in English language teaching. Jurnal Cakrawala Pendidikan, 39(2), 319331.

https://doi.org/10.21831/cp.v39i2.30065
Toquero, C. M. (2020). Challenges and opportunities for higher education amid the COVID-19 Pandemic: The Philippine context. Pedagogical Research, 5(4), em0063. https://doi.org/10.29333/pr/7947

Xiao, J. (2019). Digital transformation in higher education: critiquing the five-year development plans (2016-2020) of 75 Chinese universities. Distance Education, 40(4), 515-533. https://doi.org/10.1080/01587919.2019.16 80272

Zhou, L., Wu, S., Zhou, M., \& Li, F. (2020). 'School's out, but class' on', the largest online education in the world today: Taking China's practical exploration during the COVID-19 epidemic prevention and control as an example. SSRN Electronic Journal. https://doi.org/10.2139/ssrn.3555520 